\title{
First record of Centris hyptidis Ducke, 1908 (Hymenoptera: Apidae: Centridini) in State of Maranhão, Brazil
}

\author{
Carlos L. Neves Junior ${ }^{1= \pm}=\mathbb{(}$, Harryson C. Barros², Márcia M. C. Rêgo ${ }^{2(\mathbb{C}}$ \\ ${ }^{1}$ Programa de Pós-Graduação em Entomologia, Universidade Federal de Viçosa, Viçosa, MG, 36570-900, Brazil. ${ }^{2}$ Departamento de \\ Biologia, Universidade Federal do Maranhão, São Luís, MA, 65080-805, Brazil. \\ 表牛Corresponding author: carlos.njr@outlook.com
}

\section{Edited by: Alberto M. Silva-Neto}

Received: February 02, 2020. Accepted: March 30, 2020. Published: July 01, 2020.

Abstract. The unprecedented record of the species Centris (Paracentris) hyptidis Ducke, 1908 in the State of Maranhão, Brazil, is documented. A single female was collected during a visit on a Chamaecrista ramosa (Vogel) (Fabaceae) flower on an island in the America's Delta, Maranhão $(-2.715922,-42.200054)$, which is deposited in the Bee Collection of the Federal University of Maranhão. Such appointment contributes to the knowledge of the faunal composition of bees in the State of Maranhão, as well as the distribution of the species C. hyptidis in Brazilian territory.

Keywords: bees, new distribution, oil collector.

Centridini bees are divided into approximately 250 solitary species occurring in the Neotropical region and part of the Nearctic region (Silveira et al. 2002; Michener 2007; Moure et al. 2012a). Centridini females collect floral oils for food (Neff \& Simpson 1981; Buchmann 1987) and nest building (Jesus \& Garófalo 2000), making this the tribe with the largest number of floral oil collecting species, accounting for $73 \%$ of visits recorded in oil producing plants (Machado 2004), such as plants of the families Malpighiaceae and Krameriaceae.

Centris Fabricius, 1804 and Epicharis Klug, 1807 are the only two genera that make up the Centridini tribe, with Centris being the genus with the largest number of species, reaching the range of 230 valid species (Moure et al. 2012b). In Brazil, this genus has been documented in several ecosystems, such as dunes and restinga (Albuquerque et al. 2007; Oliveira et al. 2010; Rêgo \& Albuquerque 2012; Gostinski et al. 2016), caatinga (Aguiar et al. 2003; Aguiar et al. 2005; Batalha-Filho et al. 2007; Lopes et al. 2010), and cerrado; in the latter, with greater diversity (Ramos et al. 2007; Mesquita et al. 2009; Mesquita \& Augusto 2011).

Although apifaunistic sampling are made in Brazil, not all areas of the country are contemplated with such works. Thus, by conducting new research, new occurrences of bees can be recorded in different locations, which is a major factor for the knowledge of existing species in Brazil and elsewhere. In the present work, the unprecedented occurrence of the species Centris (Paracentris) hyptidis Ducke, 1908 in the state of Maranhão is documented. According to Vivallo \& Melo (2009) and Moure et al. (2012b), the distribution of this species was restricted to the Brazilian Northeast states (except Alagoas, Maranhão and Piauí), Goiás, Minas Gerais and Tocantins (Fig. 1).

A single female (Fig. 2) was collected during a visit on a Chamaecrista ramosa (Vogel) H.S Irwin \& Barneby var. Ramosa flower, in a restinga area on Grande do Paulino Island, Tutóia, Maranhão (-2.715922, $-42.200054)$, between 07:00 and 08:00, on June 25, 2018. The specimen is deposited in the Bee Collection of the Federal University of Maranhão / LEACOL-UFMA.

The new occurrence of $C$. hyptidis mentioned here highlights the importance of conducting further research and inventories of bees, in order to constantly contribute to the updating of Brazilian fauna data. Bees contribute immensely to ecosystem services by pollinating plants, and there is often a close relationship between these two groups. Bees of the genus Centris, for example, have a strong connection with tropical plants of the Malpighiaceae and Krameriaceae families (Buchmann 1987), these invertebrates being important players in the pollination of these plants. Thus, knowing the species of bees in a region and their distribution also contributes to the understanding of the botanical profile presented in that location.

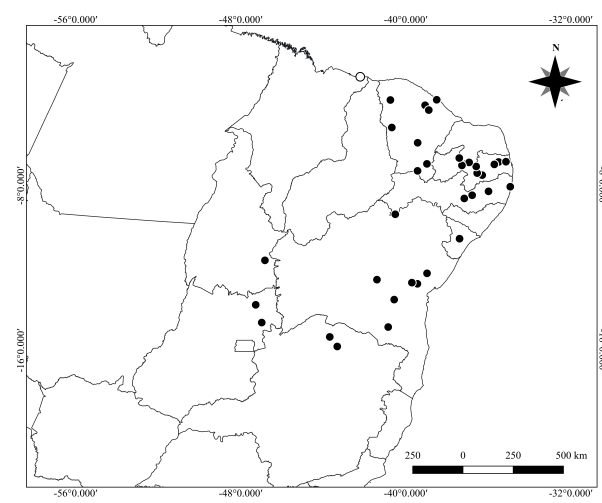

Figure 1. Occurrence of Centris hyptidis Ducke, 1908 in the Brazilian states. Black circle: Vivallo \& Melo (2009) and Moure et al. (2012b); White circle: new record.

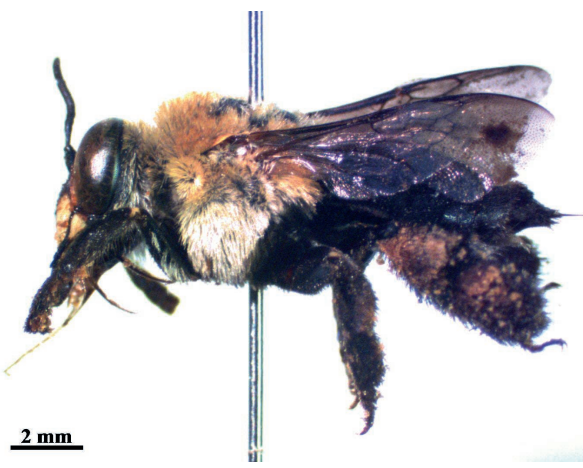

Figure 2. Female specimen of Centris (Paracentris) hyptidis Ducke, 1908 in lateral view. Scales in $\mathrm{mm}$. 
Centris hyptidis still has distribution restricted to a few Brazilian states, taking into consideration the country's large territory. It is possible that, with future research, new records of this species will be documented in other Brazilian states, and mainly in the states of Alagoas and Piauí, located in the northeast region, just like Maranhão.

\section{Acknowledgements}

FAPEMA for the funding, Dr. José Eustáquio dos Santos Junior (UFMG) for identifying the specimen and Dr. Felipe Vivallo (UFRJ) for confirming the identification and support for the publication of this new occurrence.

\section{Authors' contributions}

Carlos L. Neves Jr. collected the specimen in the field and wrote the manuscript Harryson C. Barros assisted in the collection of the specimen and contributed to the revision of the manuscript; Márcia M. C. Rêgo contributed substantially to the design of the work.

\section{References}

Aguiar, C. M. L.; Zanella, F. C. V. (2005) Estrutura da Comunidade de Abelhas (Hymenoptera: Apoidea: Apiformis) de uma Área na Margem do Domínio da Caatinga (Itatim, BA). Neotropical Entomology, 34: 15-24. doi: 10.1590/S1519-566X2005000100003

Aguiar, C. M. L.; Zanella, F. C. V.; Martins, C. F.; Carvalho, C. A. L. (2003) Plantas visitadas por Centris spp. (Hymenoptera: Apidae) na caatinga para obtenção de recursos florais. Neotropical Entomology, 32: 247-259. doi: 10.1590/S1519-566X2003000200009

Albuquerque, P. M. C.; Camargo, J. M. F.; Mendonça, J. A. C. (2007) Bee community of a beach dune ecosystem on Maranhão Island, Brazil. Brazilian Archives of Biology and Technology, 50: 1005-1018. doi: 10.1590/S1516-89132007000700012

Batalha-Filho, H.; Nunes, L. A.; Pereira, D. G.; Waldschmidt, A. M. (2007) Inventário da fauna de abelhas (Hymenoptera, Apoidea) em uma área de Caatinga da região de Jequié, BA. Bioscience Journal, 23: 24-29.

Buchmann, S. L. (1987) The ecology of oil flowers and their bees Annual Review of Ecology, Evolution, and Systematics, 18: 343-69.

Gostinski, L. F.; Carvalho, G. C. A.; Rêgo, M. M. C.; Albuquerque, P. M. C. (2016) Species richness and activity pattern of bees (Hymenoptera, Apidae) in the restinga area of Lençóis Maranhenses National Park, Barreirinhas, Maranhão, Brazil. Revista Brasileira de Entomologia, 60:319-327. doi: 10.1016/j.rbe.2016.08.004

Jesus, B. M. V.; Garófalo, C. A. (2000) Nesting behaviour of Centris (Heterocentris) analis (Fabricius) in southeastern Brazil (Hymenoptera, Apidae, Centridini). Apidologie, 31: 503-515. doi: 10.1051/apido:2000142

Lopes, M. T. R.; Reis, A. S.; Souza, B. A.; Pereira, F. M.; Neves, L. S. M. L.; Pereira, L. A.; Rocha, F. S. B.; Vieira Neto, J. M. (2010) Levantamento da fauna e plantas apícolas na Embrapa Meio-Norte, em Teresina, PI. Embrapa Meio-Norte - Boletim de Pesquisa e Desenvolvimento (INFOTECA-E).

Machado, I. C. (2004) Oil-collecting bees and related plants: a review of the studies in the last twenty years and case histories of plants occurring in NE Brazil. In: Freitas, B. M.; Pereira J. O. P. (Eds.). Solitary bees - Conservation, rearing and management for pollination. Fortaleza, Imprensa, pp 255-281.

Mesquita, T. M. S.; Augusto, S. C. (2011) Diversity of trap-nesting bees and their natural enemies in the Brazilian savanna. Tropical Zoology, 24: 127-144

Mesquita, T. M. S.; Vilhena, A. M. G. F.; Augusto, S. C. (2009) Ocupação de ninhos-armadilha por Centris (Hemisiella) tarsata Smith, $1874 \mathrm{e}$ Centris (Hemisiella) vittata Lepeletier, 1841 (Hymenoptera: Apidae: Centridini) em áreas de cerrado. Bioscience Journal, 25: 124-132.

Michener, C. D. (2007) The Bees of the World, 2a Ed. The Johns Hopins University Press, Baltimore.

Moure, J. S.; Urban, D.; Melo, G. A. R. (2012a) Catalogue of
Bees (Hymenoptera, Apoidea) in the Neotropical Region. http://www.moure.cria.org.br/index. Access on: 31.i.2020.

Moure, J. S.; Melo, G. A. R.; Vivallo, F. (2012b) Centridini Cockerell \& Cockerell, 1901. In Moure, J. S.; Urban, D.; Melo, G. A. R. (Orgs). Hymenoptera. In: Catalogue of Bees (Hymenoptera, Apoidea) in the Neotropical Region. http://www.moure.cria.org.br/catalogue. Access on: 13.iii.2010.

Neff, J. L.; Simpson, B. B. (1981) Oil-collecting structrures in the Anthophoridae (Hymenoptera): Morphology, function and use in systematics. Journal of the Kansas Entomological Society, 54: 95123.

Oliveira, F. S.; Mendonça, M. W. A.; Vidigal, M. C. S.; Rêgo, M. M. C.; Albuquerque, P. M. C. (2010) Comunidade de abelhas (Hymenoptera, Apoidea) em ecossistema de dunas na Praia de Panaquatira, São José de Ribamar, Maranhão, Brasil. Revista Brasileira de Entomologia, 54: 82-90. doi: 10.1590/S008556262010000100010

Ramos, M. C.; Rêgo, M. M. C.; Albuquerque, P. M. C. (2007) Ocorrência de Centris (Hemisiella) vittata Lepeletier (Hymenoptera: Apidae: Centridini) no Cerrado s.l. do Nordeste do Maranhão, Brasil. Acta Amazonica, 37: 165-168. doi: 10.1590/S0044-59672007000100022

Rêgo, M. M. C.; Albuquerque, P. M. C. (2012) Biodiversidade de abelhas em zonas de transição no Maranhão. In: Ribeiro MF (ed.) III Semana dos Polinizadores: palestras e resumos, Embrapa Semi-Árido, 249: 36-57.

Silveira, F. A.; Melo, G. A. R.; Almeida, E. A. B. (2002) Abelhas Brasileiras: Sistemática e Identificação. Belo Horizonte.

Vivallo, F.; Melo, G. A. R. (2009) Taxonomy and geographic distribution of the species of Centris of the hyptidis group (Hymenoptera: Apidae: Centridini), with description of a new species from central Brazil. Zootaxa, 2075: 33-44. 